\title{
Iranian Studies
}

\section{Familiar and Foreign: Identity in Iranian Film and Literature}

\section{Esmaeil Haddadian-Moghaddam}

To cite this article: Esmaeil Haddadian-Moghaddam (2018): Familiar and Foreign: Identity in Iranian Film and Literature, Iranian Studies, DOI: 10.1080/00210862.2018.1428151

To link to this article: https://doi.org/10.1080/00210862.2018.1428151

册 Published online: 31 Jan 2018.

Submit your article to this journal $[\pi$

Џ Article views: 11

Q View related articles $\longleftarrow$

View Crossmark data $₫$ 


\section{Review}

Familiar and Foreign: Identity in Iranian Film and Literature, Manijeh Mannani and Veronika Thompson (eds.), Edmonton: AU Press, 2015, paperback, ISBN 978-1927356-86-9, 264 pp.

The above book is based on a call for papers (p. 13), acknowledging the financial support of the Government of Alberta (a free pdf version of the book is available). The book contributes to current scholarship on the intersection of identity and art/literature in Iran from various angles; aiming to inform and enlighten a broad range of readership including the public and the business community about a different face of Iran. This is a lofty aim, though it seems that projecting it on such a heteronomous group remains a challenge less explored in the book. The book, as a final product of a collective work, benefits from an elegant and yet simple layout and cover design.

According to the editors, Manijeh Mannani and Veronica Thompson, the Iranian identity is above all informed by the tradition-modernity dialectic, which has continued to manifest itself not only in the people's daily life and beliefs but in their perceptions of self, sexuality, gender roles, and the construction of diasporic identities, among others. This unresolved dialectic thus contributes to the misconception by the West, and each case study in the book aims to highlight the fluid concept of identity, questioning the "one-dimensional and shallow representations of Iranians that circulate unexamined in the West" (p. 12). A fluid identity informed by the tradition-moder- 
nity duality is then what the West misses in its understanding of Iran. So how does each chapter in the book address the misunderstanding of Iranian identity by the West?

Chapter 1, written by Safaneh Mohaghegh Neyshabouri, deals with the "Development of the Artistic Female Self in the Poetry of Forugh Farrokhzad," a poet whose image and poetry continue to attract researchers as well as enthusiastic admirers, most recently with the publication of her love letters by Farzaneh Milani. The author argues that Forugh's image and works are representative of the "confessional school of poetry," something possibly distinct from the earlier varieties, and she struggled to cope with the established poetic forms and the Iranian-Islamic tradition's take on the role of women. Examples of a progressive (as opposed to regressive?) self-actualization (more clarification of this theme would have been helpful here) are then explored through samples of her poetry. Confessional poetry, perhaps a universal value in the reception of intimate poetry, can be a window into those unexplored layers of life in Iran, but then it only reaches those who read poetry.

Chapter 2, by Farideh Dayanim Goldin, explores the "Impact of the Persian Language on Iranian Women's Confessional Literature.” This long chapter (one paragraph is repeated on p. 54) starts with an interesting question: "is it possible that Persian could have impeded Iranian women's literary aspirations, especially in the genre of life narratives?" The interest nevertheless ends there, because instead of any empirical evidence, several words (e.g. arusi, zan, mard), in light of SapirWhorf hypothesis about language relativity, are given to suggest that the introduction of Islam and Arabic (the author does not mention the linguistic exchanges that followed) somehow (we do not know) made the present-day Persian and society patriarchal. As a result, Iranian women autobiographers have had to suffer because, as the author implies, Arabic is linguistically unrelated to Persian, because Iranians have learned to be discreet and speak and write indirectly. The argument is hardly convincing. The chapter then picks up another interesting lead, i.e. the sudden "surge of self-revelation” in women's autobiographies (mostly in English) due to commercial consideration, nostalgia, and the West's curiosity about Iran. As an example, Azar Nafisi's Reading Lolita in Tehran (2003) and some responses to it are discussed to suggest that such books are testimony to the new orientalist discourse insofar as they are written in non-Persian languages. The author disagrees with the idea that autobiography is a "culture-bound genre" and hopes for a day when more Persian autobiographies will appear. Autobiography, especially anything coming from Iran, as Milani argues, remains "a costly enterprise" (Veils, p. 58), we wonder whether the cost has anything to do with the Persian language.

Chapter 3, written by Mannani, is a long critical review of Fatemeh Keshavarz's Jasmine and Stars: Reading More than Lolita in Tehran (2007), itself a response to Nafisi's portrait of Iran in the years following the revolution. Mannani manages to show how, despite some truth in Keshavarz's project, the latter, and similar critics, have reduced Nafisi's autobiography to a political statement in light of "extratextual factors" (p. 73). Drawing on the author's term "autobiomythography, following Michael Brenton's article, we are told that Keshavarz's project in presenting the 
good side of Iran is itself selective and biased (p. 68) and tainted with "didactic exaggeration" (p. 64) and "uninformed anger" (p. 70), among others. Having not yet read Nafisi's book, I can only recall what Sherlock Holmes said to Dr. Watson in the Granada adaptation of "The Adventure of Shoscombe Old Place." Staring at a hot pot of food, Holmes used the expression of "deep waters," to describe both the food's appearance and the complexity of the case they were investigating. The author's hope for a realistic picture of Iran and for the development of a critical voice devoid of "intimidation and judgment" is well placed, as indeed, in virtue of analogy, a jump over the "deep waters."

Chapter 4, by Mostafa Abedinifard, studies "Dialogues with Self and Other in Marjane Satrapi's Persepolis and Persepolis 2." Here the author praises Satrapi for imitating a "critical dialogue with Iranian culture" (p. 83), "the Other" (p. 84), and the self through the innovative medium of the graphic novel, a method they call "revolutionary" for two reasons: first, her "self-revelation surpasses that of her Iranian predecessors," and second, in the use of "image-text" (p. 86). Drawing on the close reading of some panels from the stories, such things as veiling, censorship (internal and external), cultural schizophrenia, and sexual segregation are explored in the context of Iran. The second part of the chapter discusses how Satrapi's graphic and narrative style, her "successful eclecticism" (p. 95), and her use of metonymy serve her artistic purposes. Apart from a typo in the reference given for Chute (p. 95) and the repetition of one sentence (p. 94), reading this section which combines insights and theories from literary studies, women's studies, memory, and not least graphic studies is informative.

The study of identity in Iranian film and literature returns to the latter in chapter 5 with the exploration of "Personal Identities in Zoya Pirzad's 'Like all the Afternoons."” Pirzad's works, which are argued to present Iranian "middle class lives" (p. 113), continue to attract scholarly attention and promise to provide some insights on the circulation of Persian literature abroad. The author, Madeleine Voegeli, presents a case study of three protagonists in the short story collection Like all the Afternoons. Whereas the housewife in "The Stain" is happy with her "uncomplaining perseverance," her counterpart's enjoyable private moments in "Mrs. F is a fortunate woman" are offset by "accomplishing her household chores even more assiduously than usual" (p. 119). Life, in general, is no better for the recently retired "Mr. F" in "The desired life of Mr. F" because "the life circumstances presented in these three short stories are not eclectic or singular" (p. 125). With a typo in the second appearance of Akbari (p. 120), this reading works to illustrate a common fact that modern life in Iran is hardly any different from the rest of the world.

A comparison of the short story "Such" by Ghazaleh Alizadeh with Goli Tarraqi's Khabe-e zemestani (1998) sets the stage for the next chapter by Blake Atwood, "Anxious Men: Sexuality and Systems of Disavowal in Contemporary Iranian Literature." Drawing on Eve Sedgwick's notion of "homosexual panic" and what we may call the reverse order of closet movement in Iran, Atwood explores the transformation of the "homoerotic culture" and its manifestation in "Such." While it is true that homosexuality and its disavowal discourse remain taboo in Iran-which is worthy of further studies - the author warns against any "universalist approach to queer theory that does 
not take stock of "the complexity of the formation of sociality and sexuality" in Iran. Although examples of such complexities are explored in the way men bond together and turn to their mothers and the like ("female observation"), none of these are specific to Iranian men. Furthermore, the author's reading of "Such" and Khabe-e zemestani is not entirely convincing. One reason is that there are healthy Iranian men who, without being homosexual, without negating their sexuality, without any subjective categorization, remain men, with whom the Western world will continue to engage without seeking advice from their alter-females.

Chapter 7, "Reading the Exile's Body: Deafness and Diaspora in Kader Abdolah's My Father's Notebook" is an interesting study by Babak Elahi that looks at the role of sign language in writing and translating the self in exile, thus offering "an embodied sense of cultural identity that is not available either in written or in spoken language" (p. 150). The author explores Abdolah's experience in exile and his use of sign language to suggest that his novel offers "a third option outside of the speech/ writing dichotomy" (p. 154), a space that is traveled both physically and linguistically, with translation binding the two together. However, despite an exhaustive account, I am not sure how "the embodied language of gesture," itself based on a literary trope (which nevertheless maximizes Ishmael's story), translates in the proper and metaphorical senses (the former being what we typically understand by translation between two languages, the latter being anything beyond it). The strength of the chapter nonetheless is its interdisciplinarity, offering a fresh insight on the role of language in exile.

Chapter 8 is about "Persian Literature of Exile in France: Goli Taraqqi's Short Stories." Working from the premise that the literature of exile is defined by three kinds of experiences (thematic, stylistic, and generic), Laetitia Nanquette studies these aspects in three short stories by Taraqqi by first presenting a summary of each story (each has a hero or antihero), and then a comparison of metaphors and structure to reveal how exile gives rise to "stylistic evolution" (p. 181). The study of generic experience of exile in Taraqqi's work is most revealing: while indirect language (here in a tale) in Iran is a strategy to avoid censorship, it becomes "a tool to reinforce discourse on the Other" in exile. The fact that Taraqqi and similar Iranian authors and translators continue to publish in Iran rather than abroad reveals a conformity habitus (following Pierre Bourdieu's sociology) less explored and acknowledged, as are many of the interesting claims in this chapter.

A book informed by the tradition-modernity duality in Iran would not have been complete without reference to farang, farangi and farangestan, terms that generally denote the Other, and this is the topic of Goulia Ghardashkhani, whose research appears in chapter 9: "Farang Represented: The Constriction of Self-space in Goli Taraqqi's Fiction." Farang is said to reveal three layers of meaning: a desirable object of emulation, meaning coming from confrontation, and meaning coming from living farang, creating a "third space" from which Tarraqi is writing. These layers are further explored in a lengthy, rather tedious, exposition of the two short stories "Gol-haye Shiraz" and "Madam Gorgeh" with a passing uncritical reference to cultural translation, following Bhabha. "Narration," hence counter-narration becomes the "third space" where the Iranian self, identity, and ambiguities of the 
new space are played out. A game, in other words; again following Bourdieu, if you will.

In chapter 10, "Film as Alternative History: The Aesthetic of Bahram Beizai," a revised version of an earlier published piece, Khatereh Sheibani argues that Beizai's films depart from "the nationalist and Islamic interpretation" (p. 213) of history, in the way it has been written in the Islamic and Iranian traditions in a "self-glorifying" style. Despite the appeal of the subject, the piece reads like a graduate paper with lots of technical terms. Do we really need to know about "the violation of the 180-degree rule" and Alain Renais' Muriel ou le temps d'un retour (1963) when the overall aim of the book is some form of enlightenment in the general sense of the word. Maybe. There are also several claims which are either contradictory or unsubstantiated, one being the absence of notions of masculinity and femininity in the preBeizai movies history. The overall argument in this chapter seems to get lost in an attempt to enforce a feminist reading on "Beizai's rehistoricizing of the past and the way it problematizes the status quo" (p. 211).

The last chapter, another revised version of a previously published piece, coauthored by William Anselmi and Sheena Wilsons, discusses "Technologies of Memory, Identity, and Oblivion in Persepolis (2007) and Waltz with Bashir (2008)." While enough has been said about Persepolis previously here, more than ten pages are again allocated to an analysis of the movie. The comparison of Persepolis with Waltz with Bashir (a movie unrelated to Iran) is problematic, though the comparison is in itself well done. The concluding chapter nevertheless has a sharp critical take on the role of media in constructing memory "as-it-happens ... to us, the orphans of critical humanism" (p. 255).

It could be asked whether the book meets its intended objective. Each of the articles, worthy in their own right, could have been published separately (as is the case with the last two chapters), but in a book which aims to cater equally to Western media, governments, and businesses (p. X) it is hard to say. Better editing and more refined aim and readership could have brought the project to a better conclusion. Still, the underlying critique of the book, i.e. the West is failing to see Iran in its entirety, does not seem to offer anything new. The idealized/non-idealized public and the audience projected by the authors interested in all things Iranian are to some extent familiar with the different faces of Iran (whatever that might be), thanks to the increase in technological advances available and generally accessible at a reasonable price in Iran, and the rise of the Iranian diaspora, who, as unofficial ambassadors of Iran, represent other possible faces of Iran. What would perhaps be more fruitful is to explore the extent to which such an ideal understanding of Iran informs and possibly changes the West's interpretation of current events, and the role of Iran and Iranians (as opposed to the Iranian state) in it.

\section{References}

Benton, Michael. "Literary Biomythography.” Auto/Biography 13 (2005): 206-26.

Bhabha, Homi. The Location of Culture. London: Routledge, 1994. 
6 Review

Bourdieu, Pierre. The Field of Cultural Production: Essays on Art and Literature. Cambridge: Polity, 1993. Milani, Farzaneh. Veils and Words: The Emerging Voices of Iranian Women Writers. Syracuse, NY: Syracuse University Press, 1992.

\section{ORCID}

Esmaeil Haddadian-Moghaddam (D) http://orcid.org/0000-0003-1001-0563

Esmaeil Haddadian-Moghaddam

University of Leuven

(C) 2018 Esmaeil Haddadian-Moghaddam

https://doi.org/10.1080/00210862.2018.1428151

D) Check for updates 